\title{
Dynamic Magnetic Compaction of Porous Materials
}

\author{
Project Accomplishments Summary \\ CRADA No. TSB-0990-94
}

Date: October 29, 1998

Revision: 1

\section{A. Parties}

The project was a relationship between the Lawrence Livermore National Laboratory (LLNL) and IAP Research, Inc.

\author{
University of California \\ Lawrence Livermore National Laboratory \\ 7000 East Avenue, L-795 \\ Livermore, CA 94550 \\ IAP Research, Inc. \\ 2763 Culver Ave. \\ Dayton, OH 45429-3723
}

\section{B. Background}

IAP Research began development of the Dynamic Magnetic Compaction (DMC) process three years before the CRADA was established. IAP Research had experimentally demonstrated the feasibility of the process, and conducted a basic market survey. IAP identified and opened discussions with industrial partners and established the basic commercial cost structure.

\section{Description}

The purpose of this CRADA project was to predict and verify optimum pressure vs. time history for the compaction of porous copper and tungsten.

LLNL modeled the rapid compaction of powdered material from an initial density of about $30 \%$ theoretical maximum to more than $90 \%$ theoretical maximum. The compaction simulations were benchmarked against existing data and new data was acquired by IAP Research. The modeling was used to perform parameter studies on the pressure loading time history, initial porosity and temperature.

LLNL ran simulations using codes CALE or NITO and compared the simulations with published compaction data and equation of state (EOS) data. This project did not involve the development or modification of software code. CALE and NITO were existing software programs at LLNL. No modification of these programs occurred within the scope of the CRADA effort. 


\section{DISCLAIMER}

This report was prepared as an account of work sponsored by an agency of the United States Government. Neither the United States Government nor any agency thereof, nor any of their employees, make any warranty, express or implied, or assumes any legal liability or responsibility for the accuracy, completeness, or usefulness of any information, apparatus, product, or process disclosed, or represents that its use would not infringe privately owned rights. Reference herein to any specific commercial product, process, or service by trade name, trademark, manufacturer, or otherwise does not necessarily constitute or imply its endorsement, recommendation, or favoring by the United States Government or any agency thereof. The views and opinions of authors expressed herein do not necessarily state or reflect those of the United States Government or any agency thereof. 


\section{DISCLAIMER}

Portions of this document may be illegible in electronic image products. Images are produced from the best available original document. 
LLNL and IAP determined the coefficients required to model powered tungsten or a suitable material of mutual choice. IAP provided the testing on this material. LLNL and IAP utilized the methodology to perform parameter studies on the pressure time history.

\section{Economic Impact}

This project aided the reversal of the trend of increased foreign manufacturing by providing a leapfrog production tool in the powdered metal industry that lowered costs and expanded markets, consequently creating a large number of jobs. IAP Research became the DMC systems integrator and ultimately the supplier of turn key systems to end user companies. This project was aligned with LLNL's core competency in Computational Sciences and Engineering, and provided useful capabilities for Engineered Materials and Applied Physics and Chemistry.

\section{Benefits to DOE}

This project was consistent with the DOE's mission of Technology Transfer and provided benefits and positive impact on both DOE and the partners. This program did not negatively impact any current DOE program.

\section{F. Industry Area}

Software

\section{G. Project Status}

This project was completed in September 1995.

\section{H. LLNL Point of Contact for Project Information}

LLNL was represented by Mr. Ron Hawke (Principal Investigator), 925/422-8679; 925/422-2964 (fax) of the Engineering Directorate.

\section{Company Size and Point(s) of Contact}

IAP Research was represented by Dr. Bhanu Chelluri, 937/296-1806; 937/296-1114 (fax). Company sales are $\$ 2.0$ million, and the company employs $<50$ people.

\section{J. Project Examples}

There were no project examples. 


\section{K. Subject Inventions}

This small value contractual mechanism did not anticipate any generation of Intellectual Property (IP) including subject inventions. To the best of our knowledge no IP was created.

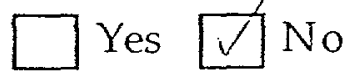

If yes, list all $\mathrm{IP}$ created under this agreement

\section{Release of Information}

I certify that all information contained in this report is accurate and releasable to the best of my knowledge.
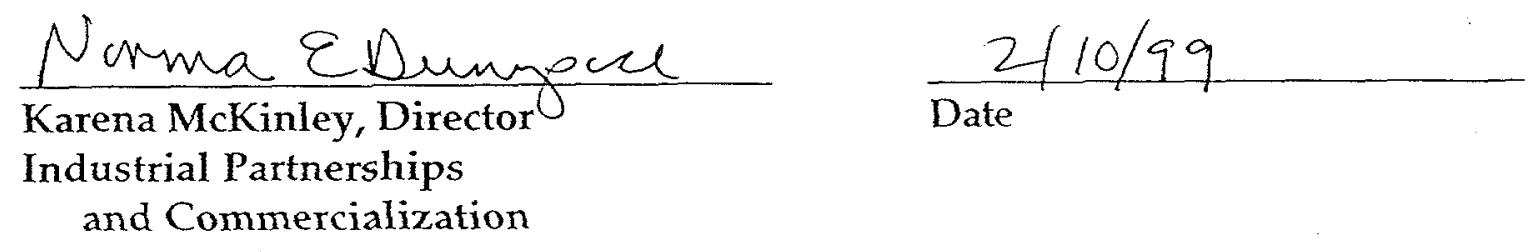

\section{RELEASE OF INFORMATION}

I have reviewed the attached Project Accomplishment Summary prepared by Lawrence Livermore National Laboratory and agree that the information about our CRADA may be released for external distribution.

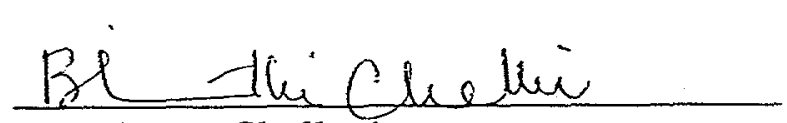

Dr. Bhanu Chelluri IAP Research

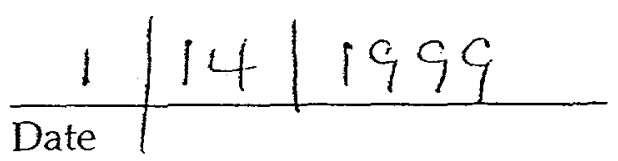

